Прунцева Г.О., канд. екон. наук, керівник ГО «Інституціональні реформи», докторант ННЦ «Інститут аграрної економіки»

\author{
РОЗВИТОК ОРГАНІЗАЦІЙНО-ЕКОНОМІЧНОГО МЕХАНІЗМУ \\ ПРОДОВОЛЬЧОЇ БЕЗПЕКИ СУСПІЛЬСТВА У СТАРОДАВНІ ЧАСИ \\ Pruntseva G.O., \\ cand.sc.(econ.), \\ head PO "Institutional reforms", \\ doctoral candidate NSC "Institute of Agrarian Economics"
}

\title{
THE DEVELOPMENT OF ORGANIZATIONAL AND ECONOMIC MECHANISM OF FOOD SECURITY IN ANCIENT TIMES
}

Постановка проблеми. Проблема продовольчого забезпечення у стародавні часи була фундаментальною проблемою функціонування суспільства. Саме у стародавні часи почали формуватись перші складові механізму забезпечення продовольчої безпеки, а розроблені у античні часи інструменти побудови ефективного ведення господарства використовуються до теперішніх часів. Історичний розвиток організаційно-економічного механізму продовольчої безпеки відбувався паралельно із виникненням і розвитком первісних держав, стародавніх культур та наукових вчень. Саме необхідність вивчення досвіду та дослідження ефективних інструментів побудови первісного організаційно-економічного механізму продовольчої безпеки у стародавні часи, що дозволили людству забезпечувати себе подуктами харчування, не померти від голоду та продовжувати цивілізаційний розвиток, і актуалізують дослідження даної тематики.

Аналіз останніх досліджень $\boldsymbol{i}$ публікацій. Дослідженню проблем продовольчого забезпечення у стародавні часи присвячували свої праці О. Гавриленко, О. Гойчук, О. Зеленська, Г. Лалаян та інші видатні українські вчені. О. Зеленська зазначає, що питання про те, чи можливо нагодувати населення Землі, чисельність якого постійно зростає, в різних інтерпретаціях вивчалося впродовж тисячоліть. О. Гавриленко пише, що в античний період на теренах півдня сучасної України утворилися та розвивалися держави (Ольвія, Херсонес, Боспор), котрі вели активну хлібну торгівлю 3 грецькими полісами, розташованими у Малій Азії та на Пелопоннесі. Через невелику кількість земель, які можна було обробляти, та їхню невисоку родючість в деяких грецьких полісах питання забезпечення громадян продуктами харчування були дуже актуальними [1, с. 47]. О. Гойчук зазначає, що проблема продовольчої безпеки і економічної безпеки лежить в основі головних положень економічного вчення Арістотеля, а найбільшого розвитку питання продовольчої безпеки отримали у працях римських дослідників Катона, Варрона, Коллумелли, забезпечення якої вони вбачали у серйозних змінах в аграрних відносинах і переходу до нових форм землеволодіння та землекористування [2, с. 30]. Отже, питання забезпечення продовольчої безпеки були актуальними у стародавні часи, успішне вирішення яких дозволило забезпечити населення продуктами харчування і забезпечити розвиток людства та суспільних відносин.

На основі виокремлених положень можна зробити висновок щодо необхідності вивчення успішного досвіду подолання проблем продовольчого забезпечення у стародавні часи.

Постановка завдання. Метою дослідження $€$ визначення основних засад продовольчого забезпечення суспільства у стародавні часи із виокремленням первісних інструментів функціонування організаційно-економічного механізму продовольчої безпеки, що дозволили забезпечити подальший розвиток суспільства.

Виклад основного матеріалу дослідження. Проблема забезпечення продуктами харчування $€$ важливим фактором розвитку суспільства протягом всього часу існування людства. Можливість забезпечення себе продуктами харчування та водою була передумовою виживання у стародавні часи, а проблема продовольчої безпеки, тобто забезпечення доступності населення до продовольства у кількості та якості, необхідних для життя суспільства, була актуальною ще за первісних часів. Саме у первісні часи почали формуватись перші складові механізму забезпечення продовольчої безпеки суспільства, як то пошук корисної їжі та створення запасів, бо відбувався природний відбір і вижити у льодовиковому періоді змогли лише ті організми, які змогли пристосуватись до навколишнього середовища та забезпечити себе продуктами харчування [3]. Основні особливості фрормування організаційно-економічного механізму продовольчої безпеки представлені в табл. 1. 


\section{Основні характеристики організаційно-економічного механізму продовольчої безпеки у первісні часи}

\begin{tabular}{|c|c|c|}
\hline ПЕРІОД & ХАРАКТЕРИСТИКА ПЕРІОДУ & $\begin{array}{l}\text { ФОРМУВАННЯ ОРГАНІЗАЦІЙНО- } \\
\text { ЕКОНОМІЧНОГО МЕХАНІЗМУ } \\
\text { ПРОДОВОЛЬЧОЇ БЕЗПЕКИ }\end{array}$ \\
\hline \multirow{2}{*}{$\begin{array}{l}\text { Давній кам'яний } \\
\text { вік (2,5 млн. р. до } \\
\text { н. е. - } 13 \text { тис. р. до } \\
\text { н. е.) - палеоліт }\end{array}$} & $\begin{array}{l}\text { Первісні колективи не мали постійного } \\
\text { місця поселення і постійно переходили з } \\
\text { одного місця у інше у пошуках їжи. } \\
\text { Основним заняттям було збиральництво } \\
\text { та полювання, тобто привласнювальні } \\
\text { форми господарства. }\end{array}$ & $\begin{array}{l}\text { Продукти колективного збиральництва та } \\
\text { полювання розподілялися на користь } \\
\text { найсильніших і запаси їжі не створювались, } \\
\text { вирішення проблеми продовольчої безпеки } \\
\text { здійснювалось шляхом пошуку нового місця } \\
\text { проживання. }\end{array}$ \\
\hline & 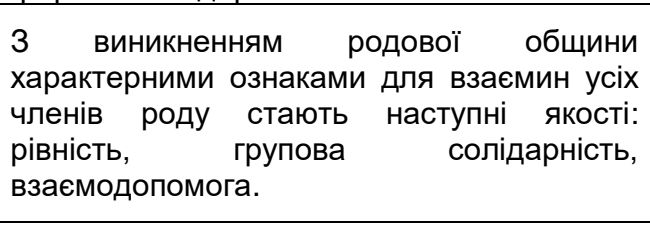 & $\begin{array}{l}\text { Відбувається зміцнення } \\
\text { зрівняльного розподілу їжі між усіма } \\
\text { членами родової общини, незалежно від } \\
\text { їхнього статусу в ній та фізичної сили. } \\
\text { Здійснюється заготівля м'яса восени на } \\
\text { зиму. }\end{array}$ \\
\hline $\begin{array}{l}\text { Середній кам'я- } \\
\text { ний вік (12 тис. p. } \\
\text { до н. е. }-7 \text { тис. p. } \\
\text { до н. е.) - мезоліт }\end{array}$ & $\begin{array}{l}\text { Поряд з настанням біоценозних змін у } \\
\text { рослинному й тваринному світі зникла } \\
\text { екологічна відповідність між потребами } \\
\text { людини у м'ясній їжі й можливістю ї̈ } \\
\text { одержання в необхідній кількості. } \\
\text { Зникнення великих стадних тварин і } \\
\text { недосконалість старих мисливських } \\
\text { знарядь у нових умовах призвели до } \\
\text { ускладнень у процесі видобування їжі. }\end{array}$ & $\begin{array}{l}\text { Проблема забезпечення роду продуктами } \\
\text { харчування все ще залишається основною, } \\
\text { яка вирішується шляхом пошуку нових } \\
\text { «кормових» територій, але в той же час } \\
\text { здійснюється розширення ресурсної бази } \\
\text { (збільшення переліку видів тварин та } \\
\text { рослин, які стали об'єктами полювання та } \\
\text { збиральництва). }\end{array}$ \\
\hline $\begin{array}{l}\text { Новий кам'яний } \\
\text { вік (7 тис. р. до } \\
\text { н.е. - } 5 \text { тис. р. до } \\
\text { н. е.) - неоліт }\end{array}$ & $\begin{array}{l}\text { Перехід від привласнюючої форори } \\
\text { господарства до виробничої. З'являються } \\
\text { нові умови життя, пов'язані з виникненням } \\
\text { землеробства та скотарства, а саме: } \\
\text { осілість, обробіток землі, вирощування } \\
\text { худоби. }\end{array}$ & $\begin{array}{l}\text { Обробіток землі, вирощування врожаю } \\
\text { стають під силу окремій сім'ї. Їй належав і } \\
\text { зібраний врожай. З'являються перші } \\
\text { надлишки. З'являються перші програми } \\
\text { навчання для мисливців і хліборобів, які } \\
\text { складались з теоретичного, практичного та } \\
\text { ритуального напрямку навчання. }\end{array}$ \\
\hline $\begin{array}{l}\text { Мідно-кам'яний } \\
\text { вік (5 тис. р. до } \\
\text { н. е. - } 3 \text { тис. р. до } \\
\text { н. е.) - енеоліт }\end{array}$ & $\begin{array}{l}\text { Перехідний період від кам'яного віку до } \\
\text { доби металів. Поряд із кам'яними } \\
\text { знаряддями праці почали виготовляти } \\
\text { мідні. Відбувся перехід від мотичного до } \\
\text { рільного землеробства. }\end{array}$ & $\begin{array}{l}\text { Основними заходами забезпечення } \\
\text { продовольчої безпеки у мідно-кам'яному віці } \\
\text { були: } \\
\text { - освоєння нових технік отримання життєво } \\
\text { необхідних харчових продуктів; } \\
\text { - створення родоплемінних запасів } \\
\text { харчування. }\end{array}$ \\
\hline $\begin{array}{l}\text { Бронзовий вік } \\
\text { (3 тис. р. до н. е. - } \\
1200 \text { р. до н. е.) }\end{array}$ & $\begin{array}{l}\text { 3'являється перший штучний метал - } \\
\text { бронза (сплав міді й олова). Родова } \\
\text { община змінюється сусідською, виникає } \\
\text { майнова нерівність. Виникають перші } \\
\text { цивілізації. }\end{array}$ & $\begin{array}{l}\text { Для періоду бронзового віку характерні } \\
\text { наступні особливості } \\
\text { продовольчої безпеки: } \\
\text { - існування відтворюючого господарства; } \\
\text { - швидкий розвиток тваринництва і орного } \\
\text { землеробства; } \\
\text { - обмін солі та металів. }\end{array}$ \\
\hline $\begin{array}{l}\text { Залізний } \\
\text { (1200 р. до н. е. - } \\
800 \text { р. до н. е.) }\end{array}$ & $\begin{array}{l}\text { Для залізного віку характерні наступні } \\
\text { особливості: зростання продуктивності } \\
\text { праці, відокремлення ремесла від } \\
\text { землеробства, здійснення переходу до } \\
\text { класового суспільства і держави, } \\
\text { вдосконалення знарядь праці тощо. }\end{array}$ & $\begin{array}{l}\text { Вдосконалення знарядь праці і зростання } \\
\text { продуктивності праці призвели до } \\
\text { збільшення кількості додаткового продукту, } \\
\text { що стало основою для вироблення } \\
\text { харчових продуктів в кількості, необхідній } \\
\text { для збільшення кількості населення та } \\
\text { суспільного розвитку. }\end{array}$ \\
\hline
\end{tabular}

\section{Джерело: узагальнено автором на основі даних [1-13]}

У період давнього кам'яного віку фрізична доступність продовольства була важливим чинником фрункціонування первісного колективу. I саме фізичну доступність продовольства, на нашу думку, можна вважати першим інструментом забезпечення продовольчої безпеки. Первісні колективи не мали постійного місця проживання і переходили з одного місця поселення у інше з метою пошуку їжі. 3 появою родової общини відбувається зміцнення традицій справедливого розподілу їжі між членами общини, незалежно від фізичної сили та статусу. Починає здійснюватись заготівля м'яса. Таким чином, процес забезпечення продуктами харчування був важливим чинником виживання первісної людини і відбувався шляхом пошуку «кормових» територій, а наприкінці палеоліту вже здійснюється заготівля їжі на зиму. 
3 появою мезоліту на Землі закінчується льодовиковий період та настає сучасний клімат. У цей період широкого розвитку набуває ускладнене збиральництво. Зникнення великих стадних тварин i недосконалість мисливських знарядь призвели до необхідності удосконалення існуючих знарядь праці. При настанні неоліту відбувається «неолітична революція», тобто перехід від привласнюючої форми господарювання до виробничої. До полювання та збирання додаються землеробство, скотарство та рибальство [4]. Змінюється спосіб життя первісного суспільства, а обробіток землі, вирощування врожаю вже стають під силу окремій сім'ї. 3'являються перші надлишки [12]. У цей період відбувається створення харчових запасів, з'являються перші програми навчання для хліборобів та мисливців, які складались з практичного, теоретичного та ритуального навчальних процесів. 3 винайденням посуду відбувається докорінна зміна харчового раціону - з'являється варена, смажена, печена їжа, приправлена різними добавками, з'являються напої [6]. Мідно-кам'яний вік ознаменувався появою мідних знарядь праці та поширенням ткацтва і гончарства. У цей період з'являється додатковий продукт, що сприяє створенню родоплемінних запасів харчування. Окрім того, почало застосовуватись іригаційне рільництво, відбувається освоєння нових технік отримання життєво необхідних харчових продуктів, як доїння худоби, пристосування худоби для запрягання для оранки, впровадження селекційних робіт [6].

3 появою бронзового віку людство починає виробляти перший штучний метал (бронзу). Родова община змінюється сусідською, з'являється майнова нерівність, відбувається виникнення перших цивілізацій. На думку К. Ясперса, стародавні культури виникли майже одночасно в трьох областях земної кулі. Це, по-перше, шумеро-вавилонська, єгипетська та егейська культури VI тис. до н.е., подруге, доарійська культура долини Інду III тис. до н.е. (пов'язана із Шумерами), по-третє, архаїчна культура Китаю II тис. до н.е. [13]. Для бронзового віку характерно існування відтворюючого господарства, швидкий розвиток орного землеробства і тваринництва, виділення скотарських племен, обмін металів (міді, бронзи, золота, бурштину) та солі. При настанні залізного віку люди почали плавити залізо. Для залізного віку характерне зростання продуктивності праці, виникнення приватної власності, відокремлення ремесла від землеробства, вдосконалення знарядь праці, застосування обертових жорнів, токарного верстату та гончарного кругу. Історичний розвиток організаційноекономічного механізму продовольчої безпеки у первісні часи представлений на рис. 1.

3 появою перших держав та розвитком іригаційних споруд сільськогосподарське виробництво стає більш ефективним. До того ж, активне будівництво доріг, мостів, прокладання нових сухопутних та водних маршрутів забезпечили активний розвиток ринків та торгівлі. Наприклад, у Стародавньому Китаї правитель Чжоу-Хань здійснив революцію в прокладанні шляхів сполучення. Таких масштабів будівництва доріг, каналів та дамб не знала жодна держава Стародавнього світу. Швидкими темпами будувалися також іригаційні споруди, які зводилися не лише для зрошування і захисту від паводків, а й як транспортні магістралі. А у Стародавньому Римі дороги будувалися згідно з усіма правилами інженерного мистецтва і до сих пір вражають своєю досконалістю.

Щодо застосування агротехнологоій, то у Стародавньому Китаї з'являється система зміни полів, при якій земельна ділянка поділялася на три частини. Дві частини засівалися, а третя рік відпочивала. Китайці стали застосовувати органічні добрива і вести боротьбу зі шкідниками сільськогосподарських рослин. Окрім цього, високий рівень знань агротехніки дозволяв китайцям одержувати гарні врожаї продовольчих і технічних культур. Нерівномірний розподіл опадів нерідко приводив до неврожаїв і голоду. Тому вже у стародавні часи китайці створювали системи штучного зрошення. У Стародавній Греції широкого розповсюдження набула зональна спеціалізація і багатогалузеве сільське господарство, так звана «середземноморська тріада» (зернові, оливки, виноград). А у Стародавньому Римі велике значення приділялось удобрюванню та обробці грунтів. Крім того, активно розвивалось тваринництво. Навколо найбільших міст Римської імперії створювалися спеціальні господарства, які забезпечували міста молоком, сиром, птицею і м'ясом. Щодо можливості забезпечення мешканцями стародавніх країн себе продуктами харчування, то, наприклад, у Стародавньому Єгипті товарне виробництво в країні було відсутне, збувався не товар, а надлишки продукції, виготовленої для власних потреб. Основні показники стану продовольчої безпеки у стародавніх цивілізаціях представлені у табл. 2.

У Месопотамії розмір орендної плати встановлювався на основі середньої врожайності землі у певній місцевості й не враховував зменшення врожаю в результаті поганого обробітку орендованої ділянки. Закони Хаммурапі передбачали встановлення норми грошової винагороди найманим працівникам. У Стародавньому Китаї у VIII р. н.е. у результаті селянського повстання до влади прийшов Ван Ман, який провів ряд реформ: землі великих землевласників були конфісковані $\mathrm{i}$ перерозподілені, велике землеволодіння обмежене, продаж землі і рабів заборонявся, на ринках були установлені тверді ціни. Держава встановлювала контроль над виробництвом і торгівлею. Однак через кілька років ці реформи були скасовані. 3 метою попередження голодних бунтів у Стародавньому Єгипті продукти харчування розподілялися між різними регіонами. 


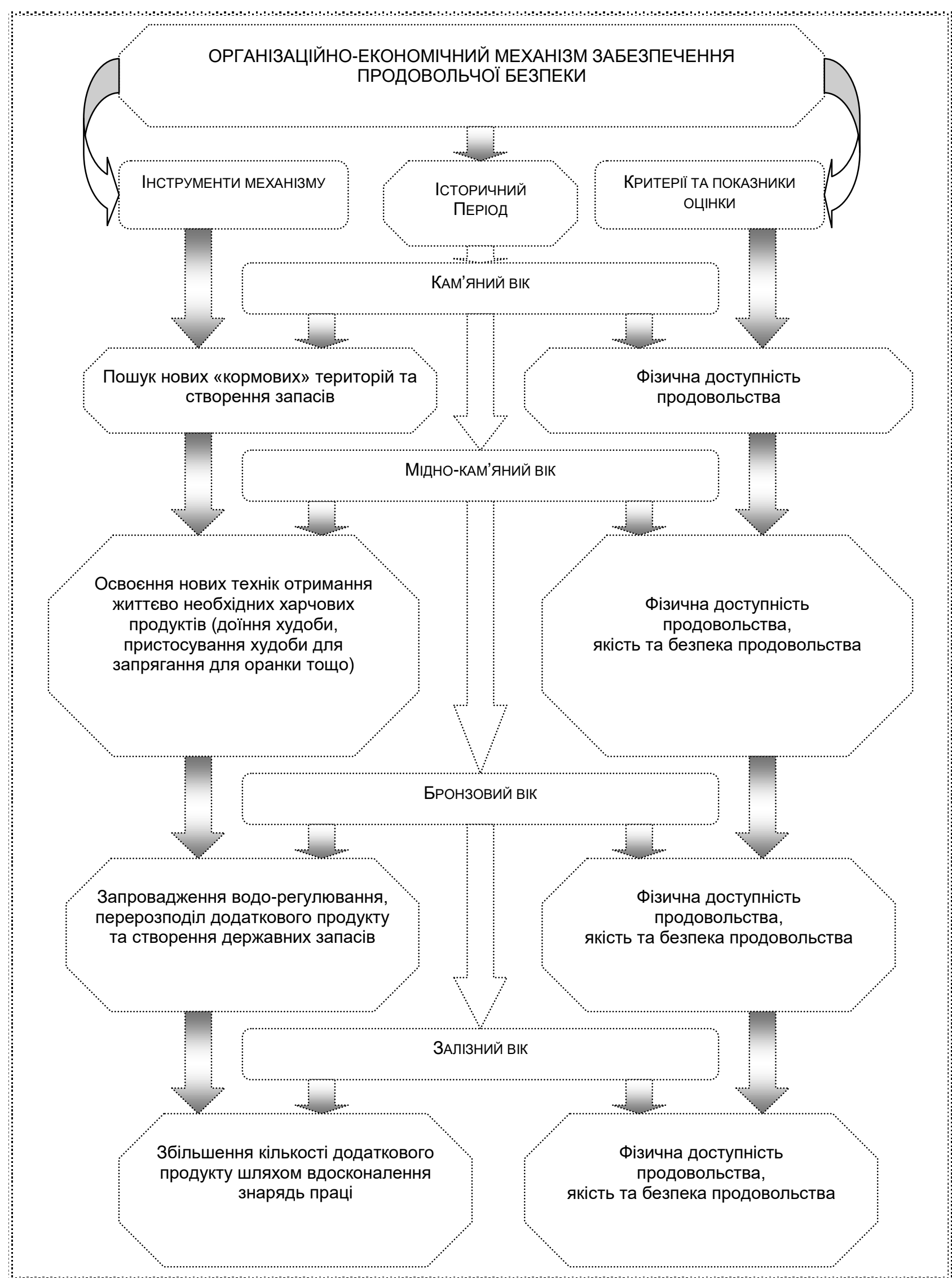

Рис. 1. Історичний розвиток організаційно-економічного механізму продовольчої безпеки Джерело: складено автором у первісні часи 


\section{Показники стану продовольчої безпеки у стародавніх цивілізаціях}

Таблиця 2

\begin{tabular}{|c|c|c|c|c|c|c|}
\hline \multirow[b]{2}{*}{ Показники } & \multicolumn{6}{|c|}{ Стародавні цивілізації } \\
\hline & $\begin{array}{c}\text { Стародавній } \\
\text { Єгипет }\end{array}$ & $\begin{array}{l}\text { Месопо- } \\
\text { тамія }\end{array}$ & $\begin{array}{c}\text { Стародавня } \\
\text { Індія }\end{array}$ & $\begin{array}{c}\text { Стародавній } \\
\text { Китай }\end{array}$ & $\begin{array}{c}\text { Стародавня } \\
\text { Греція }\end{array}$ & $\begin{array}{l}\text { Римська } \\
\text { імперія }\end{array}$ \\
\hline $\begin{array}{l}\text { Ефективність } \\
\text { функціонування } \\
\text { сільського } \\
\text { господарства }\end{array}$ & $\begin{array}{l}\text { Висока } \\
\text { продуктивність } \\
\text { с/г завдяки } \\
\text { іригаційним } \\
\text { спорудам }\end{array}$ & $\begin{array}{l}\text { Багаті вро- } \\
\text { жаї завдяки } \\
\text { системі } \\
\text { каналів і } \\
\text { дамб, які } \\
\text { мали } \\
\text { дренажне } \\
\text { призначен- } \\
\text { ня } \\
\end{array}$ & $\begin{array}{l}\text { Високий } \\
\text { рівень с/г } \\
\text { завдяки } \\
\text { іригаційним } \\
\text { спорудам }\end{array}$ & $\begin{array}{l}\text { Гарні врожаї } \\
\text { продоволь- } \\
\text { чих } \\
\text { технічних } \\
\text { культур } \\
\text { завдяки } \\
\text { агротехніці }\end{array}$ & $\begin{array}{l}\text { Гарні врожаї } \\
\text { багатогалузе } \\
\text { вого с/г }\end{array}$ & $\begin{array}{l}\text { Ефективне с/г } \\
\text { завдяки } \\
\text { удобрюванню } \\
\text { та обробці } \\
\text { грунтів }\end{array}$ \\
\hline $\begin{array}{l}\text { Регулювання рівня } \\
\text { цін }\end{array}$ & $\begin{array}{l}\text { Реформа } \\
\text { Прекрасного } \\
\text { Йосипа, яка } \\
\text { передбачала } \\
\text { здійснення } \\
\text { державних } \\
\text { закупівель для } \\
\text { зерна за } \\
\text { запобігання } \\
\text { підвищення цін }\end{array}$ & $\begin{array}{l}\text { У «Законах } \\
\text { Ешнунни» } \\
\text { встановлю- } \\
\text { вали } \\
\text { фіксовані } \\
\text { ціни на } \\
\text { основні } \\
\text { продукти } \\
\text { харчування }\end{array}$ & $\begin{array}{l}\text { Пропону- } \\
\text { валося } \\
\text { встанов- } \\
\text { лювати } \\
\text { «справедливі } \\
\text { ціни» на } \\
\text { товари }\end{array}$ & $\begin{array}{l}\text { У кожному } \\
\text { місті були } \\
\text { ринки. } \\
\text { Державними } \\
\text { актами } \\
\text { встанов- } \\
\text { лювалися } \\
\text { якість і ціни } \\
\text { на товари }\end{array}$ & $\begin{array}{l}\text { Об’єднання } \\
\text { купців } \\
\text { (фіаси) } \\
\text { допомагало } \\
\text { позиками, } \\
\text { страхувало } \\
\text { майно, } \\
\text { контролюва- } \\
\text { ло ціни, } \\
\text { надавало } \\
\text { інформацію }\end{array}$ & $\begin{array}{l}\text { Встановлюва- } \\
\text { лися загальні } \\
\text { ціни на деякі } \\
\text { товари. У кінці 1 } \\
\text { ст. до н.е. } \\
\text { з'явився закон, } \\
\text { яким встанов- } \\
\text { лювалося } \\
\text { покарання за дії } \\
\text { щодо підвищен- } \\
\text { ня цін на зерно }\end{array}$ \\
\hline $\begin{array}{l}\text { Розвиток } \\
\text { транспортної } \\
\text { інфрраструктури }\end{array}$ & \multicolumn{6}{|c|}{ Активно прокладалися водні та сухопутні маршрути } \\
\hline $\begin{array}{l}\text { Соціальні } \\
\text { програми } \\
\text { підтримки } \\
\text { населення }\end{array}$ & $\begin{array}{l}\text { Розподіл } \\
\text { продуктів } \\
\text { харчування між } \\
\text { різними } \\
\text { регіонами }\end{array}$ & $\begin{array}{l}\text { Викорис- } \\
\text { тання } \\
\text { громадою } \\
\text { зерна храму } \\
\text { у голодні } \\
\text { роки }\end{array}$ & $\begin{array}{l}\text { Суспільне } \\
\text { зерносховищ } \\
\text { е }\end{array}$ & $\begin{array}{l}\text { Стабілізація } \\
\text { цін на зерно }\end{array}$ & $\begin{array}{l}\text { Безоплатна } \\
\text { роздача } \\
\text { хліба або } \\
\text { дешевий } \\
\text { продаж }\end{array}$ & $\begin{array}{l}\text { Безоплатна } \\
\text { роздача хліба }\end{array}$ \\
\hline $\begin{array}{l}\text { Якість } \\
\text { продуктів } \\
\text { харчування }\end{array}$ & $\begin{array}{l}\text { Лікарі } \\
\text { рекомендували } \\
\text { не вживати сирі } \\
\text { продукти } \\
\text { харчування }\end{array}$ & $\begin{array}{l}\text { Звід законів } \\
\text { Хамураппі } \\
\text { регулював } \\
\text { відносини } \\
\text { щодо якості } \\
\text { товарів, } \\
\text { відповідаль- } \\
\text { ність за } \\
\text { продаж } \\
\text { неякісних } \\
\text { товарів }\end{array}$ & $\begin{array}{l}\text { Існували до } \\
\text { вимоги во } \\
\text { торгівлі } \\
\text { товарами } \\
\text { відповідної } \\
\text { якості. } \\
\text { ауюрведі } \\
\text { рекоменду- } \\
\text { валося їсти } \\
\text { свіжовигото- } \\
\text { влену іжу }\end{array}$ & $\begin{array}{l}\text { Ввели } \\
\text { посаду } \\
\text { «ринковий } \\
\text { інспектор», } \\
\text { яку певний } \\
\text { час обіймав } \\
\text { великий } \\
\text { філософ } \\
\text { Конфуцій }\end{array}$ & $\begin{array}{l}\text { У } \\
\text { Стародавній } \\
\text { Греції суворо } \\
\text { контролю- } \\
\text { вався склад } \\
\text { пива і вина }\end{array}$ & $\begin{array}{l}\text { Добре } \\
\text { налагоджена } \\
\text { система } \\
\text { контролю за } \\
\text { якістю продуктів } \\
\text { харчування, що } \\
\text { надходили у } \\
\text { продаж }\end{array}$ \\
\hline
\end{tabular}

Джерело: узагальнено автором на основі даних [1-13]

Щодо допомоги найбільш незахищеним верствам населення, то у Вавилоні жерці у храмах опікувалися малозабезпеченими, а у лихі часи брали на утримання голодуючих дітей. У Стародавньому Китаї у голодні роки переселяли голодуючих у благополучні райони країни, пустуючі площи засівали безкоштовним збіжжям, а з голодними бунтами боролися через стабілізацію цін на зерно шляхом закупівлі надлишків продукції у державні зерносховища в урожайні роки.

Висновки 3 проведеного дослідження. Отже, проблема продовольчої безпеки була актуальною ще за первісних часів і саме у стародавні часи почали формуватись перші інструменти механізму продовольчої безпеки, як то створення запасів, планування та розподіл продуктів харчування між усіма членами общини. 3 появою перших держав та розвитком іригаційних споруд сільськогосподарське виробництво стало більш ефективним, а саме: застосування агротехнологій дозволило полегшити працю людини та підвищити продуктивність сільськогосподарського виробництва, а розвиток транспортної інфраструктури забезпечив ефективний обмін та торгівлю продуктами харчування. 3 розвитком стародавніх держав відбулося регулювання цін на продукти харчування, встановлювався контроль за якістю продовольчих товарів та з'явились перші соціальні програми підтримки найбільш незахищених верств населення. Таким чином, у стародавні часи були сформовані перші принципи та складові сучасної системи продовольчої безпеки, успішне функціонування яких дозволило забезпечити подальший розвиток людства. 


\section{Література}

1. Гавриленко О. А. 3 досвіду античного законодавства про продовольчу безпеку (Самос, II ст. до н.е.): історико-правове дослідження. Форум права. 2013. № 4. С. 47-52.

2. Гойчук О. І. Продовольча безпека : монографрія. Житомир : Полісся, 2004. 347 с.

3. Прунцева Г. О. Історичний розвиток організаційно-економічного механізму продовольчої безпеки суспільства у первісні часи. "Conduct of modern science-2014": materials of the X International scientific and practical conference. Sheffield: Science and education LTD. Vol. 6. pp. 66-69.

4. Глобалізація і продовольство : монографія / П. Т. Саблук та ін. Київ : ННЦ "Інститут аграрної економіки", 2008. 632 с.

5. Горілий А. Г. Історія соціальної роботи : навч. посіб. Тернопіль : Астон, 2004. 174 с.

6. Економічна історія України: Історико-економічне дослідження: у 2 т. / Т. А. Балабушевич, В. Д. Баран, В. К. Баран та ін. Київ : Ніка-Центр, 2011. Т. 1. 696 с.

7. Елекронна бібліотека Князева. URL: http://www.ebk.net.ua (дата звернення 23.09.2019)

8. Залізняк Л.Л. Стародавня історія України. Київ : Темпора, 2012. 542 с.

9. Немченко В.В.Продовольча безпека України. Збірник наукових праць ВНАУ. 2012. № 4 (70). C. $179-182$.

10.Семенов Ю. І. Введення у всесвітню історію. Випуск І. Проблема та понятійний апарат. Виникнення людського суспільства. URL: http://scepsis.net/library/id_1040.html (дата звернення 20.09.2019)

11.Семигіна Т. В, Сухицька Н. В, Ярошенко А. О. Історія та теорія соціальної політики України: навч. посібн. Київ, НПУ імені М.П. Драгоманова, 2018. 289 с.

12.Суспільна організація за первісних часів. URL: http://elenaperexodova.blogspot.com/ 2014/09/blog-post_11.html (дата звернення 22.09.2019)

13.Ясперс К. Смысл и назначение истории. URL: https://imwerden.de/pdf/jaspers_smysl _i_naznachenie_istorii_1991.pdf (дата звернення 21.09.2019)

\section{References}

1. Havrylenko, O.A. (2013), "From the experience of ancient legislation on food security (Samos, 2nd Century BC): a historical and legal research", Forum prava, Vol. 4, pp. 47-52

2. Hoichuk, O.I. (2004), Prodovolcha bezpeka [Food security], monograph, Polissia, Zhytomyr, Ukraine, $347 \mathrm{p}$.

3. Pruntseva, G.O. (2014), "The historical development of the organizational and economic mechanism of society's food security in primitive times", "Conduct of modern science-2014", Materials of the $X$ International scientific and practical conference, [Conference proceedings of the International conference], Science and education LTD, Sheffield, Great Britain, Vol. 6, pp. 66-69.

4. Sabluk, P.T. et al. (2008), Globalizatsiia i prodovolstvo [Globalization and provision], monograph, NNTs "Institut ahrarnoi ekonomiky", Kyiv, Ukraine, 632 p. $174 \mathrm{p}$.

5. Horilyi, A.H. (2004), Istoriia sotsialnoi roboty [History of social work], Aston, Ternopil, Ukraine,

6. Balabushevych, T.A., Baran, V.D., Baran, V.K. et al. (2011), Ekonomichna istoriia Ukrainy: Istoryko-ekonomichne doslidzhennia: $v 2 t$. [Economic history of Ukraine: historical and economic research: in 2 vol.], Nika-Tsentr, Kyiv, Ukraine, Vol. 1, 696 p. 2019).

7. "Electronic library of kniazev", available at: http://www.ebk.net.ua/ (access date September 23,

8. Zalizniak, L. (2012), Starodavnia istoriia Ukrainy [The ancient history of Ukraine], Tempora, Kyiv, Ukraine, $542 \mathrm{p}$.

9. Nemchenko, V.V. (2012), "Food security of Ukraine", Zbirnyk naukovykh prats VNAU, no. 4(70), pp. $179-182$.

10.Semenov, Yu. (1997), An introduction to world history. Issue I. Problem and conceptual system. The emergence of human society, available at: http://scepsis.net/library/id_1040.html (access date September 20, 2019).

11.Semyhina, T.V, Sukhytska, N.V. and Yaroshenko, A.O. (2018), Istoriia ta teoriia sotsialnoi politiky Ukrainy [History and theory of social policy of Ukraine], NPU im. M.P. Dragomanova, Kyiv, Ukraine, 289 p.

12."A social organization in primitive times", available at: http://elenaperexodova.blogspot.com/2014/09/blog-post_11.html (access date September 22, 2019).

13.Yaspers, K. The meaning and purpose of history, available at: https://imwerden.de/pdf/jaspers_smysl_i_naznachenie_istorii_1991.pdf (access date September 21, 2019).. 